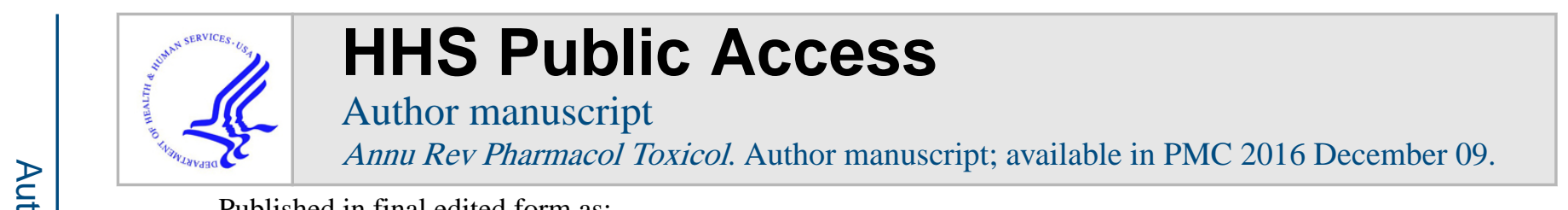

Published in final edited form as:

Annu Rev Pharmacol Toxicol. 2016 ; 56: 403-425. doi:10.1146/annurev-pharmtox-011613-135952.

\title{
G Protein-Coupled Receptor Heteromers
}

\section{Ivone Gomes ${ }^{1}$, Mohammed Akli Ayoub ${ }^{2,3}$, Wakako Fujita ${ }^{1,7}$, Werner C. Jaeger ${ }^{4,5}$, Kevin D.G. Pfleger $^{4,5,6}$, and Lakshmi A. Devi ${ }^{1}$}

Lakshmi A. Devi: lakshmi.devi@mssm.edu

${ }^{1}$ Department of Pharmacology and Systems Therapeutics, Icahn School of Medicine at Mount

Sinai, New York, NY 10029

${ }^{2}$ Biologie et Bioinformatique des Systèmes de Signalisation (BIOS) Group, INRA, UMR85, Unité Physiologie de la Reproduction et des Comportements; CNRS, UMR7247, F-37380 Nouzilly, France

${ }^{3}$ LE STUDIUM Loire Valley Institute for Advanced Studies, F-45000 Orleans, France

${ }^{4}$ Molecular Endocrinology and Pharmacology, Harry Perkins Institute of Medical Research, Nedlands, Western Australia 6009, Australia

${ }^{5}$ Centre for Medical Research, The University of Western Australia, Crawley, Western Australia 6009, Australia

${ }^{6}$ Dimerix Bioscience Limited, Nedlands, Western Australia 6009, Australia

\begin{abstract}
G protein-coupled receptors (GPCRs) compose one of the largest families of membrane proteins involved in intracellular signaling. They are involved in numerous physiological and pathological processes and are prime candidates for drug development. Over the past decade, an increasing number of studies have reported heteromerization between GPCRs. Many investigations in heterologous systems have provided important indications of potential novel pharmacology; however, the physiological relevance of these findings has yet to be established with endogenous receptors in native tissues. In this review, we focus on family A GPCRs and describe the techniques and criteria to assess their heteromerization. We conclude that advances in approaches to study receptor complex functionality in heterologous systems, coupled with techniques that enable specific examination of native receptor heteromers in vivo, are likely to establish GPCR heteromers as novel therapeutic targets.
\end{abstract}

\footnotetext{
${ }^{7}$ Current address: Department of Frontier Life Sciences, Nagasaki University, Nagasaki City, Nagasaki Prefecture 852-8588, Japan DISCLOSURE STATEMENT

K.D.G.P. is Chief Scientific Advisor of Dimerix Bioscience Limited, a spin-out company of The University of Western Australia that owns intellectual property relating to the GPCR-HIT technology. K.D.G.P. is a named inventor on issued and pending patents covering the GPCR-HIT technology (WO/2008/055313 Detection system and uses therefor). K.D.G.P. has a minor shareholding in Dimerix Bioscience. Promega provided funding to K.D.G.P.'s laboratory as a partner organization of the Australian Research Council Linkage grant LP130100037 for development of NanoBRET ${ }^{\mathrm{TM}}$ technologies. The other authors are not aware of any affiliations, memberships, funding, or financial holdings that might be perceived as affecting the objectivity of this review.
} 


\section{Keywords}

allosterism; dimerization; oligomers; proximity-based assays; biochemical fingerprint; heterodimerization; bivalent ligands

\section{INTRODUCTION}

Many family A G protein-coupled receptors (GPCRs) have been reported to form receptor heteromers (1-5), the accepted definition of which is a "macromolecular complex composed of at least two (functional) receptor units [protomers] with biochemical properties that are demonstrably different from those of its individual components" (5, p. 132). Many studies have used recombinant receptors expressed in heterologous cells to study the formation of GPCR complexes (1-5); however, only a subset have demonstrated that such complexes exhibit novel biochemical properties; i.e., a biochemical fingerprint, and very few have provided evidence for GPCR heteromerization in native tissue (see Supplemental Tables 1 and 2; follow the Supplemental Materials link in the online version of this article or at http:// www.annualreviews.org). For the above definition to be fulfilled, it is necessary to provide evidence that the receptors exist in a macromolecular complex and exhibit novel properties as a consequence. Ideally, to establish the physiological or pathological relevance of a heteromer, this evidence should be specific to the heteromer complex in a native tissue. However, this is technically challenging. Establishing the heteromer's biochemical fingerprint in heterologous cells with rigorous controls is therefore an important first step. Beyond establishing novel molecular pharmacology in heterologous systems, it is important to obtain evidence for close receptor proximity and functional interaction in native tissue and/or in vivo. Proximity-based assays have recently been developed to probe close physical relationships between two GPCRs not only in heterologous cells but also in tissue sections (6-8). Finally, to critically evaluate the heteromer pharmacology and to explore the presence and biological roles of these heteromers in vivo, reagents that can disrupt or modulate native GPCR heteromer function are being developed (9-16). In this review, we describe the criteria suggested by investigators in the field (5) that need to be addressed to establish heteromer function in vivo. We also highlight examples of heteromer combinations that fit these criteria. The specific examples are given in Table 1 and Supplemental Tables 1 and 2; select examples are included in the text.

\section{CRITERIA, TECHNIQUES, AND REAGENTS FOR DEMONSTRATING G PROTEIN-COUPLED RECEPTOR HETEROMERIZATION}

In recent years, a large number of studies investigated various aspects of heteromerization. Owing to the use of varied tools and techniques, the studies have led to interesting but sometimes opposing results $(17,18)$. To allow for a thorough and critical evaluation of heteromers in endogenous systems, investigators in the field have proposed a set of standards (5). We have grouped these standards into three criteria that are summarized in the sidebar, Criteria for G Protein-Coupled Receptor Heteromers in Native Tissue. In this review, we describe different techniques and reagents to test the criteria (summarized in 
Figure 1), give examples of GPCR pairs that fulfill them, and discuss some of the limitations of the techniques that have challenged the field in establishing a role for heteromers in vivo.

\section{CRITERIA FOR G PROTEIN-COUPLED RECEPTOR HETEROMERS IN NATIVE TISSUE}

\section{Criterion 1: Heteromer components should colocalize and physically interact}

This criterion can be addressed by demonstrating the following in native tissue of wildtype (WT) animals (and not of animals that lack one of the receptors): (a) colocalization of the receptor protomers within a cellular compartment, $(b)$ coimmunoprecipitable interacting complexes, and $(c)$ close proximity between receptor protomers that would allow interactions to enable allosterism.

\section{Criterion 2: Heteromers should exhibit properties distinct from those of the} protomers

This criterion can be addressed by demonstrating the following: (a) unique signaling, i.e., biochemical fingerprint (pharmacological/signaling/trafficking properties), only in cells expressing both receptor protomers; and (b) replication of the unique biochemical fingerprint in tissues from WT animals but not in tissues from animals that lack one of the receptors.

\section{Criterion 3: Heteromer disruption should lead to a loss of heteromer-specific} properties

This criterion can be addressed by demonstrating that the heteromer disruption leads to the following: (a) loss of colocalization, (b) loss of isolatable interacting complexes, (c) loss of unique biochemical fingerprint, and $(d)$ loss of heteromer-specific in vivo function.

\section{Criterion 1: Heteromer Components Should Colocalize and Physically Interact, Either Directly or via Intermediate Proteins Acting as Conduits for Allosterism}

This criterion is the one that has been most frequently applied. Ideally, a combination of colocalization studies, proximity-based methods, and coimmunoprecipitation assays should be used with native cells or tissues to address this criterion (see Figure 1 and Supplemental Tables 1-3). This is because colocalization techniques alone do not generally provide sufficient subcellular resolution to establish close proximity; coimmunoprecipitation can occur even if the receptors are too far apart to allosterically modulate one another in a complex. Proximity-based assays have recently been used to show the closeness between protomers. However, proximity-based assays for studies in native tissues are relatively new. In this review, the studies that demonstrate colocalization and coimmunoprecipitation are considered as the ones that address this criterion (Figure 1 and Supplemental Tables 1-3). Below, we describe approaches used to demonstrate colocalization, close proximity, and complex formation between two receptor protomers in native cells or tissues.

In situ hybridization, immunohistochemistry, and immunoelectron microscopy

-For two protomers to form a heteromer in vivo, they must be expressed in the same cell. 
In situ hybridization has been used to assess the coexpression of receptor protomers in individual cells within a tissue (Supplemental Table 3). The use of fluorescent labels for in situ hybridization (19) has helped to facilitate the localization of GPCRs in the same cell, because two different fluorescent probes can be concurrently visualized (Supplemental Table 3). However, in situ hybridization indicates the presence of mRNAs but not colocalization of receptor protein to the same cellular compartment. Hence, additional visualization techniques such as immunohistochemistry are needed (reviewed in 20).

Antibodies generated in two different species and that selectively recognize individual protomers have been used to examine the colocalization of two receptors within an individual cell in tissue sections (Supplemental Table 3). Immunoelectron microscopy allows one to demonstrate localization of two protomers in the same cellular and subcellular compartment (7) (Supplemental Table 3). Immunohistochemical methods can detect the presence of individual protomers in the same cell and even in the same cellular compartment, but the resolution of this method is insufficient to establish if the proteins are close enough to enable allosteric modulation (21). Advances in super-resolution microscopy may make an important contribution in this respect (22).

Proximity-based biophysical techniques-Proximity-based biophysical techniques have been the favored approaches for establishing close proximity of protomers. An extensive review of the multiple forms and applications of these techniques has recently been published (23). Resonance energy transfer (RET) has been the mostly widely used technique to monitor GPCR complexes, primarily because of its powerful ability to monitor in real time and in live cells (23). Data from RET assays have some aspects/caveats that must be taken into account. First, a conformational change between tagged proteins in a complex may reduce/eliminate a RET signal even though the proteins remain associated (24, $25)$; thus, a lack of RET does not unequivocally establish the absence of protein-protein proximity, nor does a loss of RET necessarily indicate the dissociation of proteins from a complex. Second, these experiments require attaching luciferase/fluorescent protein tags to host proteins; such tags have the potential to interfere with the ability of the host protein to interact with other proteins and/or function correctly $(24,26)$. Third, if expression levels are high enough (i.e., excessive overexpression of exogenous proteins in heterologous cells), crowding of acceptor and donor can produce bystander RET, even though the tagged proteins lack affinity for one another $(27,28)$. Time-resolved fluorescence RET (TR-FRET) is an approach that is used to determine close proximity between two protomers in native tissue. This technique, based on transfer of energy from a lanthanide donor, such as europium or terbium cryptate, to an acceptor, such as Alexa Fluor 647, allophycocyanin, or d2 (29), has been adapted to examine close proximity between GPCR protomers in native tissue sections (30-32). Long-lived emission from lanthanide donors allows prolonged excitation of acceptor molecules in the absence of an external excitation source (29). Moreover, a positive signal observed when donor-acceptor pairs are $\sim 9 \mathrm{~nm}$ apart suggests close proximity to facilitate allosteric interactions (29). The adaptations of this technique for detecting heteromers in native tissue include incorporating the donor/acceptor pairs into antibodies (antibody-aided FRET) or ligands (ligand-aided FRET) to individual protomers. These approaches are described below. 
1. Antibody-aided FRET: Proximity between two receptors in vivo is assessed by combining the use of receptor-selective antibodies and TRFRET. An important caveat is that antibody selectivity must be rigorously demonstrated using tissue from animals that lack the individual protomers. The demonstration of $\mathrm{GABA}_{\mathrm{B}}$ receptor tetramers in the brain is an example of the use of this approach (31).

2.

Ligand-aided FRET: This method assesses the proximity between two receptors in vivo using a combination of fluorescently labeled ligands that are selective for each protomer. The cognate ligand of one protomer is labeled with an energy donor, and that of the other protomer with an energy acceptor fluorophore. Precautions for these types of studies include ensuring use of ligands selective for individual protomers, understanding how fluorescent labels affect ligand properties, and obtaining a positive signal in tissues from wild-type (WT) animals but not in tissue sections from animals that lack one of the protomers or in WT tissues in which the complexes have been disrupted. Ligand-aided FRET has been validated with the dopamine D1-D3 heteromer in a stably expressing, heterologous cell line (33). In addition, a proof-of-concept study demonstrated the presence of oxytocin receptor homomers in mammary glands $(30,32)$, thus illustrating a potential application of this technique for detection of GPCR heteromers in tissues.

Proximity ligation assays-Proximity ligation assays (PLAs) have become the assays of choice for demonstrating the proximity of a variety of proteins, including GPCRs, in native tissue (23). In PLAs, the tissue is incubated with receptor-selective antibodies and then with species-specific secondary antibodies coupled to complementary oligonucleotide sequences that are known as PLA probes $(34,35)$. If the antibodies to the two different protomers are $\checkmark 17 \mathrm{~nm}$ apart, the PLA probes are ligated (21). Amplification of the sequence within the probes using fluorescently labeled oligonucleotides leads to a signal that can be visualized by fluorescence microscopy. Key factors in the success of this technique include the quality of fixed tissue, the specificity and bivalent character of the primary antibodies, and the use of proper controls (36). These controls include demonstrating the presence of PLA signal in tissue sections from WT animals but not in sections from animals that lack one of the receptor protomers or carry out PLA in the absence of primary antibodies. The dual recognition of PLA probes reduces the problem of antibody cross-reactivity, which allows the use of antibodies that might not give conclusive results on their own in immunofluorescence or immunohistochemistry. However, the requirement for dual recognition of PLA probes puts further constraints on the method because the antigenic epitopes must be available for targeting and must not be obscured by protein-protein interactions (37). The PLA assay has been used to explore heteromerization of cannabinoid CB1 and CB2 receptors in the pineal body and the nucleus accumbens (34), and heteromerization of dopamine D2 and adenosine A2A receptors in the striatum (35). Furthermore, a combination of PLA and electron microscopy has been used to identify CB1-CB2 heteromers in the basal ganglia of macaques (38). 
Coimmunoprecipitation-Coimmunoprecipitation is the most commonly used technique to provide evidence that two GPCR protomers are in a complex (Supplemental Tables 1 and 2). With this approach, membrane preparations are solubilized, one of the receptor protomers is immunoprecipitated by the use of protomer-selective antibodies, and the partner protomer is visualized by subjecting the immunoprecipitates to Western blot analysis using antibodies to the partner protomer (reviewed in 39, 40). It is critical to demonstrate selectivity of the antibodies to the individual protomers; this is done by using tissues from WT animals and animals that lack individual protomers.

Fluorescent animals-A recent advance in the field is the generation of transgenic animals that express fluorescently tagged receptors. Animals that express individual GPCR protomers that are differentially tagged with two different fluorescent proteins have aided in the visualization of the two receptors in the same cells [and in some cases, within the same cellular compartment (41)]. For example, mice expressing enhanced green fluorescent protein-tagged $\delta$ opioid receptor $(\delta \mathrm{OR})$ and mCherry-tagged $\mu$ opioid receptor $(\mu \mathrm{OR})$ demonstrated colocalization of $\delta \mathrm{OR}$ and $\mu \mathrm{OR}$ in specific brain regions involved in pain regulation (41). In addition, substantial overlap of expression of the two receptors at the plasma membrane was found in some cases (41). Interacting complexes were also isolated using coimmunoprecipitation, which provides evidence for the presence of $\delta \mathrm{OR}-\mu \mathrm{OR}$ complexes (41). A caveat to the results from these animals is that fluorescent tags on the protomers might influence the localization and interaction between protomers. Nonetheless, these animals will be useful for further exploration of $\delta \mathrm{OR}-\mu \mathrm{OR}$ heteromer formation and function in vivo.

It is important to note, however, that although the techniques described under this criterion demonstrate colocalization, close proximity between two receptor protomers, and the formation of complexes, the results do not demonstrate that the two protomers allosterically modulate each other to influence function. In the future, the use of small photoactive crosslinking agents, together with immunoprecipitation of cross-linked protomers and mass spectrometric identification of the two receptor protomers (and no other proteins), would provide evidence for their direct interaction and would potentially reveal insights into domains of interaction.

\section{Criterion 2: Heteromers Should Exhibit Properties Distinct from Those of the Protomers}

The novel pharmacology of heteromers has attracted significant attention owing to their potential utility for the development of new therapeutics. The biochemical fingerprint of a heteromer includes pharmacological, signaling, and trafficking properties (5). Most studies that examine the biochemical fingerprint of a heteromer have used heterologous cells engineered to express recombinant receptors. The advantages of such a system are that (a) it enables control of the expression level of GPCR protomers; $(b)$ cells that express individual protomers can be used as controls, thus aiding in assigning the observed pharmacology/ signaling to the heteromer; and $(c)$ it addresses the question of whether the expression of the two receptors is sufficient to reveal the biochemical fingerprint of the heteromer in a native tissue, thus supporting the idea that the two receptors are necessary and sufficient to yield the heteromer's novel pharmacology in the native tissue (5). Thus, to fulfill criterion 2 for 
GPCR heteromerization in a tissue, one must demonstrate that the heteromer exhibits a biochemical fingerprint when the two receptors are coexpressed in heterologous cells, that this fingerprint is present in tissue from WT animals (but not from animals that lack one of the receptor protomers), and that heteromer disruption leads to attenuation or loss of the biochemical fingerprint. In the following sections we describe the analysis of the biochemical fingerprint by examining pharmacological, signaling, and trafficking properties of the heteromers.

Modulation of ligand-binding properties-Studies using radioligand-binding assays have suggested that GPCR heteromerization can alter the binding properties of protomerselective ligands (Figure 1). These alterations include (a) an increase/decrease in binding affinity of protomer-selective ligands [as seen with $\delta \mathrm{OR}-\mu \mathrm{OR}$ or dopamine D2 receptor (D2R)-somatostatin receptor (SSTR)2 (42-45)]; (b) a decrease/increase in binding affinity of ligands selective for one protomer without a change in affinity of ligands to the partner protomer [e.g., $\kappa \mathrm{OR}-\mu \mathrm{OR}$ and $\mu \mathrm{OR}$-neurokinin 1 receptor (NK1R) $(46,47)]$; (c) a decrease/ increase in the binding affinity of ligands that are selective for one protomer in the presence of a cognate ligand of the partner protomer [e.g., D2R-adenosine A2A receptor and D2Rserotonin 5- $\mathrm{HT}_{2 \mathrm{~A}}$ receptor (47-50)]; and $(d)$ binding cooperativity (either positive or negative) using a combination of ligands that target each protomer [e.g., $\delta \mathrm{OR}-\kappa \mathrm{OR}, \mathrm{a}_{1 \mathrm{~A}}$ adrenoceptor (AR)-D4R or chemokine CCR2-CXCR4/CCR5 heteromers (51-53)]. Together, these results indicate that heteromerization may allosterically modulate receptor function. Support for this conclusion comes from studies that have assessed allosteric modulation of the binding properties of $\delta \mathrm{OR}-\mu \mathrm{OR}$ heteromers (54).

Modulation of signaling properties-Studies using signaling assays such as receptormediated G-protein activity, adenylyl cyclase activity, ERK1/2 phosphorylation, and $\beta$ arrestin-mediated signaling have provided evidence that heteromerization can change signal transduction (see Table 1 and Supplemental Tables 1 and 2). These changes include the following: (a) The presence of one protomer increases/decreases signaling by the partner protomer [e.g., 5-HT2A-mGlu 2 (55), $\delta$ OR-CB1 (56), $\beta_{1} \mathrm{AR}-\beta_{2} \mathrm{AR}$ (57), and $\beta_{2} \mathrm{AR}-$ prostaglandin E2 receptor 1 (EP1R) (58)]; (b) an agonist of one protomer signals through a different $\mathrm{G}$ protein subunit in cells expressing the heteromer compared with cells that express the homomer [e.g., $\delta \mathrm{OR}-\mu \mathrm{OR}$ and D2R-ghrelin (GSHR1) receptor (42, 59-61)]; (c) the signaling pathway activated by the heteromer and/or its localization is different from that activated by each protomer [e.g., $\delta \mathrm{OR}-\mu \mathrm{OR}, \delta \mathrm{OR}-\mathrm{CB} 1, \mathrm{a}_{2 \mathrm{c}} \mathrm{AR}-\mathrm{AT} 1$, and PAR1-PAR2 (42, $56,62-65)] ;(d)$ there is a decrease in the potency of the agonist for one protomer [as seen for $\mu \mathrm{OR}$-nociceptin receptor (NOP) and $\delta \mathrm{OR}-\mathrm{CB} 1(56,66)]$; (e) there is an increase/ decrease in signaling with a combination of agonists to both protomers [as reported for $\delta$ OR- $\kappa$ OR, $\mu$ OR-CB1, and AT1-CCR2 heteromers $(25,51,67)] ;(f)$ a combination of agonists for both protomers either fails to elicit signaling [e.g., $\delta \mathrm{OR}-\mathrm{CXCR} 4$ heteromers (68)] or leads to novel signaling different from that of the individual protomers [e.g., $a_{2 c} A R-$ AT1 (65)]; ( $g$ ) an antagonist to one protomer blocks signaling by the partner protomer [as seen for A2A-CB1, A2A-D2R, AT2-relaxin/insulin-like family peptide receptor 1 (RXFP1) or CCR2-CCR5/CXCR4 heteromers $(53,69-72)]$; $(h)$ the combined use of antagonists of both protomers blocks signaling from the heteromer [as indicated with AT1-CCR2 and 
PAR1-PAR4 heteromers $(25,73)]$; and $(i)$ potentiation of signaling by one protomer occurs in the presence of nonsignaling concentrations of ligands for the partner protomer [e.g., $\delta \mathrm{OR}-\mu \mathrm{OR}$ heteromers $(74,75)]$. It should be noted that, in the majority of the cases, these changes could arise from signaling crosstalk and not directly from allosteric receptor modulation. In this context, studies with reagents that selectively disrupt/block the heteromer would be useful to tease apart the extent to which the signaling properties represent the biochemical fingerprint of the heteromer.

Modulation of trafficking properties-A number of studies have assessed trafficking properties of protomers in the GPCR heteromeric complex (Supplemental Tables 1 and 2). These include investigations of the maturation of heteromers and their agonist-mediated internalization from the cell surface. Most of these studies have been carried out using heterologous cells because of the lack of suitable receptor-specific antibodies and the ease with which trafficking can be investigated in detail in heterologous cells. Studies of heteromer trafficking from the cell surface have reported that: (a) the presence of one protomer changes the localization of the partner protomer from an intracellular compartment to the cell surface [e.g., $\delta \mathrm{OR}-\mathrm{CB} 1$ heteromers (56)]; (b) the presence of one protomer decreases agonist-mediated internalization of the partner protomer [e.g., $\delta \mathrm{OR}-\kappa \mathrm{OR}$ or PAR1-PAR2 heteromers $(51,64)]$; (c) some but not all agonists to one protomer promote internalization of both protomers [e.g., $\delta \mathrm{OR}-\mu \mathrm{OR}$ heteromers $(9,76,77)]$; for $\delta \mathrm{OR}-\mu \mathrm{OR}$ heteromers, a peptide corresponding to transmembrane helix 1 of $\mu \mathrm{OR}$ disrupted the heteromer and attenuated agonist-mediated internalization of both protomers (9); $(d)$ agonist to one protomer but not to the partner protomer promotes internalization of both protomers [e.g., $\mu \mathrm{OR}$-somatostatin $2 \mathrm{~A}$ and $\mu \mathrm{OR}-\mathrm{GRPR}$ heteromers $(12,78)$ ]; (e) agonist to one protomer promotes the internalization of the partner protomer [e.g., $\mu \mathrm{OR}-\mathrm{GRPR}$ and A2A$\mathrm{D} 2 \mathrm{R}(12,79,80)]$; $(f)$ trafficking of the protomers is changed from a recycling compartment (for receptor homomers) to a degradative compartment [e.g., $\delta \mathrm{OR}-\mu \mathrm{OR}$ and V1aR-V2R heteromers $(9,81,82)$ ]; and $(g)$ agonist treatment leads to changes in the extent of $\beta$-arrestin recruitment and $\beta$-arrestin-mediated signaling [e.g., $\alpha_{1 \mathrm{~A}} \mathrm{AR}-\mathrm{CXCR} 2$, CXCR4CXCR7, and $\alpha_{2 c}$ AR-AT1 heteromers $\left.(65,83,84)\right]$.

In addition to receptor internalization, cell surface expression of heteromers appears to be differentially modulated (85). A chaperone protein, ERp57, is reportedly required to facilitate the formation and maturation of $\beta_{2} \mathrm{AR}$-AT1 heteromers (86). Calreticulin was reported to be needed for the maturation of AT1-B2 bradykinin receptor heteromers (87). Receptor transporter protein 4 (RTP4) increased the amount of the $\delta \mathrm{OR}-\mu \mathrm{OR}$ heteromer at the cell surface (88). Together, these studies support the ideas that heteromers undergo maturation in a manner that is distinct from that of the protomers, and that various chaperone proteins may help to facilitate these maturation events.

As described above, the novel pharmacology of heteromers has been investigated by the use of ligand binding, signaling, and trafficking assays that have compared changes in pharmacology with coexpression of the two receptors to that of individual receptors (Figure 1). An emerging technique to study the novel pharmacology is the GPCR Heteromer Identification Technology (GPCR-HIT; Dimerix Bioscience). This approach monitors heteromer-specific pharmacology owing to its configuration, which keeps monomers, 
homomers, and other complexes in the cell in the dark (Figure 2) (89). Moreover, it can be utilized with multiple assay platforms $(23,90-92)$; the main examples employ bioluminescence RET (BRET) (83, 93-97), enzyme fragment complementation (98), or TRFRET (33). Because the GPCR-HIT assay can be configured for assessment of heteromerspecific $\mathrm{G}$ protein coupling, $\beta$-arrestin recruitment, and ligand binding (23), this technology should be useful to characterize newly detected heteromers in future studies. Furthermore, BRET ligand-binding assays have recently been developed using NanoBRET ${ }^{\mathrm{TM}}$ (Promega) (99), which are beginning to be used to monitor the dynamics of heteromerization (23). Together, these techniques should help to define the biochemical fingerprint of native GPCR heteromers.

\section{Criterion 3: Heteromer-Selective Reagents Should Alter Heteromer-Specific Properties}

This criterion tests whether an endogenous heteromer plays a physiological or a pathological role. Ideally, this would be demonstrated by using agents/tools that disrupt the endogenous heteromer and attenuate heteromer-selective signaling, thereby altering heteromer function in vivo. A few tools have been developed, including membrane-permeable peptides that target the predicted heteromeric interface(s) and transgenic animals that express mutant protomers unable to form heteromers. A major focus has been on the generation of tools that recognize and/or activate heteromers in native tissue. These include heteromer-selective antibodies that can detect heteromers under normal and pathological conditions, and ligands (bifunctional/multifunctional, bivalent, or small molecule) that selectively target heteromers (see Supplemental Tables 1 and 2). In the following section, we first describe studies with reagents to study GPCR heteromers in vivo, and then we discuss tools to disrupt GPCR heteromers.

Heteromer-selective antibodies-Antibodies that selectively recognize an epitope in the heteromer (but not individual protomers) have been useful in demonstrating the presence, and regulation of the abundance, of GPCR heteromers in vivo (13-16). Such heteromer-selective antibodies have been reported to block heteromer-mediated signaling and to detect changes in heteromer levels under pathological conditions $(13,15,16)$. For example, a $\delta \mathrm{OR}-\mu \mathrm{OR}$-selective antibody was found to block heteromer-mediated signaling and to detect increased heteromer abundance in specific brain regions under conditions that lead to development of tolerance to morphine $(13,98)$. Heteromer-selective antibodies could also be of therapeutic importance, as seen for a $\delta \mathrm{OR}-\mathrm{kOR}$-selective antibody that increased 6OR-mediated antinociception in animals (14). Another example involves an AT1-CB1selective antibody, which was used to demonstrate increased heteromer levels in the liver following ethanol-induced fibrosis and to show that the heteromer-mediated signaling is abolished by antibody pretreatment (16). Together, these studies indicate that heteromerselective antibodies could be useful tools to detect GPCR heteromers in tissue sections, to evaluate the heteromer's biochemical fingerprint, to determine the contribution of heteromers to a given physiological response, and to aid in the development of assays to identify heteromer-selective drugs with therapeutic potential. A caveat with heteromerselective antibodies is that they may stabilize transient interactions between the two protomers; thus, caution needs to be exercised while interpreting results from studies with these antibodies. 
Bivalent ligands-A number of bivalent ligands (which have a pharmacophore selective for one protomer joined by a spacer arm to a pharmacophore selective for the partner protomer) have been used to explore a variety of heteromers, in particular those in which one of the protomers is $\mu \mathrm{OR}(100-103)$. Administration of bivalent ligands targeting $\delta \mathrm{OR}-\mu \mathrm{OR}$, $\mu \mathrm{OR}-\mathrm{CB} 1$, or $\mu \mathrm{OR}-\mathrm{mGlu}_{5}$ heteromers can produce antinociception that is greater than what is observed with morphine but without side effects such as tolerance, dependence, or respiratory depression $(100-102,104)$. A bivalent ligand targeting the $\mu$ OR-CCR5 heteromer was found to be more effective than a mixture of the two antagonists for inhibiting viral entry into cells (103), which suggests that such bivalent ligands may be clinically useful against HIV infection. A bivalent ligand (KDN-21) targeting $\delta \mathrm{OR}-\kappa \mathrm{OR}$ heteromers selectively antagonized $\delta$ OR 1 and אOR2 without inducing antinociception (105). In an attempt to generate ligands that exhibit antinociception with reduced side effects, bivalent peptides were designed to possess the sequences of both $\delta / \mu \mathrm{OR}$ agonist and a NK1 antagonist (106). These bivalent peptides had agonistic activity for opioid receptors and antagonistic activity for NK1 (106); further studies are needed to determine if their activity is $\mu \mathrm{OR}-\mathrm{NK} 1$ heteromer-specific and to compare their antinociceptive activity with that of morphine. Bivalent ligands that can promote specific conformational changes within $\mathrm{MT}_{1^{-}}$ $\mathrm{MT}_{2}$ homo- and heteromers have also been reported; both pharmacophores of such ligands appear to bind to the two protomers of the dimer (107).

Bifunctional/multifunctional ligands-Bifunctional or multifunctional ligands targeting the $\mu \mathrm{OR}-\mathrm{NK} 1$ heteromer have been generated. These molecules combine the structures of the $\mu \mathrm{OR}$ agonist fentanyl and the NK1 antagonist L732138 (108). These compounds exhibit $\mu \mathrm{OR}$ agonistic and NK1 antagonistic activity, but studies are needed to address their selectivity for the $\mu \mathrm{OR}-\mathrm{NK} 1$ heteromer in native tissue. In addition, a multifunctional $\delta / \mu \mathrm{OR}$ agonist/NK1 antagonist compound (named TY027) was synthesized and shown to exhibit excellent antinociceptive efficacy, low abuse liability, and no opioidrelated emesis or constipation (109). However, it is not clear if this compound targets the $\mu \mathrm{OR}-\mathrm{NK} 1$ or the $\delta \mathrm{OR}-\mathrm{NK} 1$ heteromer.

Small-molecule ligands-High-throughput screening of large libraries of small drug-like compounds using assays that measure heteromer-selective signaling has the potential to identify heteromer-selective/biased agonists. However, appropriate controls, i.e., cells that individually express each receptor or that express unrelated receptors, are needed. Because the $\delta$ OR- $\mu$ OR heteromer was found to signal via $\beta$-arrestin recruitment, which could be substantially blocked by the heteromer-selective antibody, Dimerix's GPCR-HIT assay was used to screen for $\delta \mathrm{OR}-\mu \mathrm{OR}$ ligands using DiscoveRx's PathHunter platform that assays $\beta$ arrestin recruitment (98). This screen led to the identification of CYM51010, which exhibited higher efficacy in cells expressing both receptors and in tissues from WT animals, as compared with cells expressing individual receptors or tissues from animals lacking the individual receptors (98). Furthermore, CYM51010 exhibited antinociceptive activity similar to that of morphine; this activity was partially blocked by a $\delta \mathrm{OR}-\mu \mathrm{OR}$ heteromer-selective antibody, which implied that the in vivo effects of CYM51010 were, at least in part, mediated by this heteromer (98). Chronic administration of CYM51010 led to a lower development of tolerance compared with morphine (98), which suggests that this compound 
could be developed as an analgesic with reduced side effects. Further studies, including those with animals lacking individual protomers, are needed to assess the specificity of CYM51010 and to characterize its pharmacological properties.

$N$-naphthoyl- $\beta$-naltrexamine (NNTA), which targets the $\kappa \mathrm{OR}-\mu \mathrm{OR}$ heteromer (based on in vitro assays), was found to exhibit $\mu \mathrm{OR}$ antagonistic activity (110). Interestingly, its intrathecal administration was found to induce antinociception without the development of tolerance, physical dependence, or place preference (110). Although the antinociceptive activity of NNTA was absent in mice lacking $\mu \mathrm{OR}$ (110), further studies are needed to demonstrate that this activity is mediated by $\mathrm{kOR}-\mu \mathrm{OR}$ heteromers and not by other heteromer pairs involving opioid receptors and/or other GPCRs. Also, studies are needed to explore whether NNTA exhibits a $\mathrm{xOR}-\mu \mathrm{OR}$ biochemical fingerprint in cells or in tissues that express both receptors.

Many of the studies that characterize heteromer-selective ligands have not been carried out in animals that lack individual receptors. Therefore, questions remain as to whether the heteromers are, in fact, the sole targets of the above-mentioned ligands.

Membrane-permeable peptides-Membrane-permeable peptides fused to a peptide sequence that disrupts the predicted heteromeric interface have been used to evaluate heteromerization of a variety of GPCRs (Supplemental Tables 1 and 2). In the case of $\delta O R-$ $\mu \mathrm{OR}$ heteromers, systemic administration of a membrane-permeable peptide fused to a peptide corresponding to transmembrane helix 1 of $\mu \mathrm{OR}$ decreased the levels of $\delta \mathrm{OR}-\mu \mathrm{OR}$ interacting complexes that could be isolated from native tissue, and increased morphinemediated analgesia (9). In another study, a membrane-permeable peptide fused to a peptide corresponding to the distal C-tail of $\delta \mathrm{OR}$ reduced the antidepressant and anxiolytic effects of a $\delta O R$ agonist (10). A membrane-permeable fusion peptide unique to the $\mu$ OR1D isoform that targets $\mu$ OR1D-GRPR heteromers was used to explore a role for this heteromer in morphine-induced pruritus; systemic administration of the peptide led to a decrease in morphine-induced scratching without affecting morphine-induced analgesia (12). Because the effects of membrane-permeable peptides have not been examined in animals that lack individual protomers, it is not clear if the observed effects are the result of disruption of the heteromer.

Pepducins (peptides derived from a GPCR intracellular loop linked to a lipid) have provided another approach to explore heteromer function in vivo (111). Cell-penetrating PAR1 pepducins produced striking neointimal hyperplasia in WT mice that was ablated in either PAR1- or PAR2-deficient mice, which suggests a role for PAR1-PAR2 heteromers in the response. This study also showed that PAR1 and PAR2 are in interacting complexes that have novel properties (111). Additional studies that show that PAR1-pepducin affects the complex formation and the biochemical fingerprint of PAR1-PAR2 heteromers are needed to support a role of these heteromers in hyperplasia.

Mice expressing dimerization-deficient mutants-Transgenic animals expressing receptor protomers that are unable to dimerize have helped provide evidence to support the involvement of heteromers in receptor function in vivo. For example, common variants of 
human D4R, but not a less common variant (D4.7R), dimerize with D2SR (112). Knockin mice that harbor the human D4.7R variant have selective impairment of D4R-mediated modulation of neurotransmitter release (112). This result suggests that loss of interaction between D2R and D4R affects neurotransmitter release and supports a role for their interaction in pathologies that involve the D4R system. Another example is a study that examines $5-\mathrm{HT}_{2 \mathrm{~A}}-\mathrm{mGlu}_{2}$ heteromers using viral delivery of a mutant $\mathrm{mGlu}_{2}$ receptor (with substitutions in the dimerization interface that eliminate interaction with $5-\mathrm{HT}_{2 \mathrm{~A}}$ ) to determine a role for this heteromer in hallucinogen-induced psychosis-like effects in mice (113). A third example is that of the $\mathrm{MT}_{1}-\mathrm{MT}_{2}$ heteromer, in which transgenic animals engineered to overexpress a nonfunctional $\mathrm{MT}_{2}$ mutant that interfered with $\mathrm{MT}_{1}-\mathrm{MT}_{2}$ heteromer formation in photoreceptor cells exhibited attenuated light sensitivity of their rod photoreceptors (114). Together, these studies show that disruption of heteromers has functional effects if the disruption leads to a loss of immunoprecipitable interacting complexes and loss of the biochemical fingerprint in heterologous systems and in endogenous tissue. A reciprocal study to help evaluate the physiological role of a heteromer would express a partner protomer in animals that lack the protomer and would test whether this leads to heteromer-complex formation and to restoration of novel pharmacology (i.e., the biochemical fingerprint associated with heteromer function).

\section{G PROTEIN-COUPLED RECEPTORS IN NATIVE TISSUES THAT FULFILL ALL THREE CRITERIA FOR HETEROMERIZATION}

As shown in Table 1 and Supplemental Tables 1 and 2, at this stage, only a handful of family A GPCR heteromers potentially fulfill the three criteria for heteromerization in native tissue. A noteworthy example is the $\delta \mathrm{OR}-\mu \mathrm{OR}$ heteromer, for which both protomers colocalize to the same cellular and subcellular compartment, as determined by immunoelectron microscopy and immunohistochemical analysis of mice coexpressing fluorescently labeled receptor protomers and with $\delta \mathrm{OR}-\mu \mathrm{OR}$ heteromer-selective antibodies $(4,115-117)$. These findings support the appropriate localization of the $\delta \mathrm{OR}-\mu \mathrm{OR}$ heteromer to address criterion 1. This heteromer exhibits unique properties (criterion 2): Whereas individual protomers exhibit $\mathrm{G}_{\mathrm{ai}}$-mediated signaling, the $\delta \mathrm{OR}-\mu \mathrm{OR}$ heteromer reportedly signals via $\mathrm{G}_{\mathrm{az}}, \beta$ arrestin or $\mathrm{Ca}^{2+}$-mediated signaling $(4,115-117)$, and the unique $\beta$-arrestin-mediated signaling can be blocked by the $\delta \mathrm{OR}-\mu \mathrm{OR}$ heteromer-selective antibody $(13,98)$. In addition, a number of reagents that target $\delta \mathrm{OR}-\mu \mathrm{OR}$ heteromers have enabled studies to address criterion 3 . These include membrane-permeable peptides that disrupt heteromers in native tissue, heteromer-selective antibodies that block heteromer-mediated signaling, bivalent ligands, and a heteromer-biased small-molecule agonist that activates heteromers (4, $115-117)$. Such evidence thus supports the idea that $\delta \mathrm{OR}-\mu \mathrm{OR}$ heteromers exist in vivo, exhibit novel pharmacology, and may be a potential therapeutic target to treat pain and related disorders. To rigorously evaluate the role of this heteromer in vivo, additional tools/ reagents such as animals that express dimerization-deficient mutant receptors and/or highly selective $\delta \mathrm{OR}-\mu \mathrm{OR}$ heteromer antagonists are needed.

A2A-D2R heteromers have also largely addressed all three criteria. In support of criterion 1 are in situ hybridization data showing that A2A mRNA is coexpressed in striatal neurons 
that express D2R but not D1R mRNA, coimmunoprecipitation studies that demonstrate complex formation, and PLAs that show their close proximity in the caudate nucleus (79, 118-121). Criterion 2 has been addressed by data that show that the heteromer exhibits a unique biochemical fingerprint in heterologous cells and in native tissue, as demonstrated by the observation that a $\mathrm{D} 2 \mathrm{R}$ agonist reduced A2A agonist-mediated signaling, and vice versa $(79,119)$. With regard to criterion 3 , a bivalent ligand that targets A2A-D2R has been shown to display higher displacement of radioligand binding than its monovalent counterparts, but only in cells that coexpress both receptors (122). Reagents that selectively disrupt A2A-D2R have not been reported; such reagents would shed light on the in vivo physiological role of this heteromer.

The $\mathrm{MT}_{1}-\mathrm{MT}_{2}$ heteromer also fulfills the three criteria for heteromerization. For criterion 1, both receptor protomers are found in photoreceptor cells from mouse retina by fluorescent in situ hybridization, they can form complexes (as evidenced by isolation of the complexes from retinal cell lysates that coexpress both receptors), and they are in close proximity in the retina (114). With respect to criterion $2, \mathrm{MT}_{1}-\mathrm{MT}_{2}$ exhibits a unique pharmacological and signaling profile in heterologous cells and in the retina. For example, occupancy of a protomer allosterically modulates binding to the partner protomer; moreover, the heteromer signals via a pathway involving phospholipase $\mathrm{C}$ and protein kinase $\mathrm{C}$, and this is not seen in mice that lack individual protomers (114). Evidence for criterion 3 comes from studies with bivalent ligands, $\mathrm{MT}_{1}$ or $\mathrm{MT}_{2}$ knockout mice, and mice that express a loss-of-function mutant of $\mathrm{MT}_{2}(107,114)$.

Recent examples of heteromers involving chemokine receptors that address all three criteria are $a_{1 A}$ AR-CXCR4 and $a_{1 B}$ AR-CXCR4 $(123,124)$, with implications for blood pressure regulation. Studies with these heteromers addressed criterion 1 using coimmunoprecipitation to show complex formation in human vascular smooth muscle cells (VSMCs) and PLAs to demonstrate close proximity in a rat VSMC line (A7r5), aortic rat VSMCs, and human VSMCs. Criterion 2 was addressed by studies that showed that CXCR4 silencing with short interfering RNA (siRNA) abolished heteromer-specific signaling, i.e., phenylephrineinduced $\mathrm{Ca}^{2+}$ fluxes and the phosphorylation of myosin light chain 2 in human VSMCs. Furthermore, CXCR4 activation enhanced the potency of phenylephrine in vivo (124). Criterion 3 was addressed by demonstrating that a peptide derived from transmembrane helix 2 of CXCR4 disrupted $a_{1 A B} A R-C X C R 4$ heteromers and inhibited $a_{1} A R$ function in VSMCs (124). However, studies using animal models need to be carried out to further the implications of these findings.

D1R-D2R is another heteromer that appears to address all three criteria. Immunohistochemistry, single-cell PCR, coimmunoprecipitation, and PLA were used to address colocalization of D1R-D2R in the striatum of neonatal mice (Supplemental Table 1). When the colocalization of D1R-D2R was examined using mice expressing D1RtdTomato and D2R-eGFP, there appeared to be a complete segregation of receptors in adult striatum (18) or $\sim 5 \%$ coexpression in neonatal striatum (Supplemental Table 1). It remains to be seen if the extent of colocalization is altered during development, in different brain regions, and/or in pathology. With regard to criterion 2, several previous studies reported unique properties of D1R-D2R (Supplemental Table 1). For example, heteromer activation 
was reported to lead to a switch in signaling from a $G_{a s^{-}}$or $G_{a i^{-}}$-mediated pathway to a $G_{a q^{-}}$ mediated pathway, and this was seen in heterologous cells, cultured striatal neurons, and endogenous striatal tissue (Supplemental Table 1). SKF83959 was reported to target D1RD2R heteromers because it was found to activate $\mathrm{G}_{\mathrm{aq}}$-mediated signaling and $\mathrm{Ca}^{+2} /$ calmodulin-dependent protein kinase II (CAMKII) only in cells that express both receptors and in striatum in vivo $(125,126)$. However, the study by Frederick et al. (18) has questioned these findings; the authors report not being able to demonstrate a clear biochemical fingerprint (i.e., $\mathrm{G}_{\mathrm{aq}}$-mediated signaling) in cells coexpressing the receptors using $\mathrm{G}_{\mathrm{aq}}$ biosensor proteins or with CODA-RET. They also went on to show that the in vivo behavioral effects of this compound depended on D1R and did not require D2R or $G_{a q}$ signaling (18). Therefore, further studies are needed to reconcile the differences seen by various investigators using different approaches to study D1R-D2R heteromers. Finally, using cell-permeable peptides targeting D1R-D2R heteromers, studies have addressed criterion 3 (Table 1; Supplemental Table 1). Membrane-permeable peptides targeting the heteromer have been reported to disrupt D1R-D2R signaling in neurons (Supplemental Table 1), decrease the level of D1R-D2R complex in the prefrontal cortex, and block heteromer-mediated signaling (127); infusion of one of these peptides into the prefrontal cortex was also found to elicit antidepressant effects (127). However, the effects of peptides on animals lacking D1R or D2R have not been reported.

The above examples of GPCR heteromers in endogenous tissue, by fitting the three criteria, highlight the need for multiple, complementary methods using selective reagents. This emphasizes the importance of developing tools and technologies that can specifically and critically evaluate the presence and function of heteromers in native tissues.

\section{CONCLUSIONS AND PERSPECTIVES}

Although family A GPCR heteromerization has been extensively studied in heterologous cells, a clear demonstration of heteromers as novel signaling units has not been provided in every case. Very few studies have demonstrated the presence of family A GPCR heteromers in native tissue that fulfill the criteria for heteromerization. A key reason for this paucity of evidence has been a lack of appropriate reagents and techniques. However, recent advances in the field, such as the development of proximity-based assays, membrane-permeable peptides that target the dimerization interface, and heteromer-selective antibodies, have begun to provide the types of tools to help address this issue. Advances in TR-FRET technology, such as antibody-aided or ligand-aided FRET that make use of protomerselective antibodies/ligands tagged with donor and acceptor pairs, would also aid in demonstrating proximity between receptor protomers in native tissue. Such approaches were used to demonstrate that $\mathrm{GABA}_{\mathrm{B}}$ receptors are present as tetramers in brain tissue (31) and to detect oxytocin receptor homomers in mammary glands $(30,32)$, and this could be extended to family A GPCR heteromers. Although heteromer-selective antibodies have been useful in detecting the increased abundance of some heteromers under pathological conditions, antibodies able to disrupt specific heteromers would help probe the function of endogenous heteromers. Identification of the heteromeric interfaces, which ought to be unique for a given GPCR heteromer, would provide a target for the generation of transgenic, 
heteromer-deficient animals. These tools could help to differentiate the contribution of the heteromer from the homomer in eliciting various biological responses.

Heteromeric interface identification would be facilitated by the crystallization of a GPCR heteromer followed by X-ray crystallography. This approach is being increasingly used to study GPCR monomer or homomer structures. Other approaches that could be used to identify heteromeric interfaces are nuclear magnetic resonance (NMR) spectroscopy and cryoelectron microscopy (cryo-EM). Immunoprecipitation and NMR were used in combination to study the interaction of p75 neurotrophin receptor with p45 and to identify the domains and residues involved in this interaction (128), but this approach has not been used to study family A GPCR heteromer structure. Neither has cryo-EM, although advances in this technique have enabled the resolution of the atomic structure of the transient receptor potential cation channel subfamily V member 1 (TRPV1), with a resolution similar to that generally observed for X-ray crystallography $(129,130)$. The identification of heteromeric interfaces for a GPCR heteromer using these biophysical approaches would facilitate modeling studies using other GPCR combinations and could help predict putative heteromeric interfaces that could then be validated in heterologous cells. Furthermore, such models could be used to facilitate in silico identification of small-molecule heteromerselective antagonists, which could then be tested for their heteromer selectivity and therapeutic potential. Moreover, it is now evident that GPCR heteromerization is tightly linked to other important concepts, including allosterism $(131,132)$ and biased signaling $(90,133)$. Therefore, new GPCR-based drug screening programs should consider, as much as possible, the potential contribution of different GPCR heteromers and their signaling pathways.

In addition to their role as tools to assess the importance of heteromerization in vivo, heteromer-selective/biased compounds or biologics, including single-domain antibodies, will provide starting points for heteromer-selective or -biased drug development programs. A key example of such a screen resulted in the identification of CYM51010 as a $\delta$ OR- $\mu$ OR-biased agonist (98), as discussed above. Most of the drugs that are currently used to target GPCRs are accompanied by undesirable side effects owing to off-target actions; GPCR heteromers, which are likely to have a restricted tissue distribution or to be upregulated in specific tissues only under pathological conditions, may thus be novel therapeutic targets for new pharmaceuticals, with fewer side effects. The realization of the therapeutic potential of GPCR heteromers will depend upon our understanding of a heteromer's pharmacological properties, both in heterologous systems and in vivo. Unlocking the physiological and pathological consequences of those properties will in turn enable their therapeutic potential to be unlocked, as it may reveal how best to modulate heteromer function for therapeutic benefit (Figure 3). Heteromers that are best characterized (Table 1), such as the $\delta \mathrm{OR}-\mu \mathrm{OR}$, are likely to be the first to be exploited clinically. Of note, eluxadoline, an orally active $\mu \mathrm{OR}$ agonist/8OR antagonist that exerts its effects through $\delta \mathrm{OR}-\mu \mathrm{OR}$ heteromers (134), has undergone Phase III clinical trials for the treatment of diarrhea-predominant irritable bowel syndrome and has been accepted for the filing of a new drug application by the FDA. 


\section{Supplementary Material}

Refer to Web version on PubMed Central for supplementary material.

\section{Acknowledgments}

We thank Dr. Salvador Sierra for critical reading of the manuscript. This work was supported in part by NIH grants DA008863 and NS026880 (to L.A.D.) and the Australian Research Council (grant DP120101297 to K.D.G.P. and M.A.A.). K.D.G.P. was an Australian Research Council Future Fellow (FT100100271) and is now a National Health and Medical Research Council R.D. Wright Fellow (1085842). The number of reported heteromers that involve family A GPCRs has been increasing exponentially over the past decade. We apologize that we have not included all in the current review owing to the space limitations; we selected a small number of reported heteromer pairs to show how they fulfill the different criteria and to articulate their possible therapeutic potential.

\section{LITERATURE CITED}

1. Milligan G, Bouvier M. Methods to monitor the quaternary structure of G protein-coupled receptors. FEBS J. 2005; 272:2914-25. [PubMed: 15955052]

2. Pin JP, Neubig R, Bouvier M, Devi L, Filizola M, et al. International Union of Basic and Clinical Pharmacology. LXVII Recommendations for the recognition and nomenclature of G proteincoupled receptor heteromultimers. Pharmacol Rev. 2007; 59:5-13. [PubMed: 17329545]

3. Lohse MJ. Dimerization in GPCR mobility and signaling. Curr Opin Pharmacol. 2010; 10:53-58. [PubMed: 19910252]

4. Gomes I, Fujita W, Chandrakala MV, Devi LA. Disease-specific heteromerization of G-proteincoupled receptors that target drugs of abuse. Prog Mol Biol Transl Sci. 2013; 117:207-65. [PubMed: 23663971]

5. Ferré S, Baler R, Bouvier M, Caron MG, Devi LA, et al. Building a new conceptual framework for receptor heteromers. Nat Chem Biol. 2009; 5:131-34. [PubMed: 19219011]

6. Ciruela F, Vilardaga JP, Fernandez-Duenas V. Lighting up multiprotein complexes: lessons from GPCR oligomerization. Trends Biotechnol. 2010; 28:407-15. [PubMed: 20542584]

7. Kaczor AA, Selent J. Oligomerization of G protein-coupled receptors: biochemical and biophysical methods. Curr Med Chem. 2011; 18:4606-34. [PubMed: 21864280]

8. Fernandez-Duenas V, Taura JJ, Cottet M, Gomez-Soler M, Lopez-Cano M, et al. Untangling dopamine-adenosine receptor-receptor assembly in experimental parkinsonism in rats. Dis Model Mech. 2015; 8:57-63. [PubMed: 25398851]

9. He SQ, Zhang ZN, Guan JS, Liu HR, Zhao B, et al. Facilitation of $\mu$-opioid receptor activity by preventing $\delta$-opioid receptor-mediated codegradation. Neuron. 2011; 69:120-31. [PubMed: 21220103]

10. Kabli N, Nguyen T, Balboni G, O'Dowd BF, George SR. Antidepressant-like and anxiolytic-like effects following activation of the $\mu-\delta$ opioid receptor heteromer in the nucleus accumbens. Mol Psychiatry. 2014; 19:986-94. [PubMed: 24061495]

11. O’Dowd BF, Ji X, O'Dowd PB, Nguyen T, George SR. Disruption of the $\mu-\delta$ opioid receptor heteromer. Biochem Biophys Res Commun. 2012; 422:556-60. [PubMed: 22583900]

12. Liu XY, Liu ZC, Sun YG, Ross M, Kim S, et al. Unidirectional cross-activation of GRPR by MOR1D uncouples itch and analgesia induced by opioids. Cell. 2011; 147:447-58. [PubMed: 22000021]

13. Gupta A, Mulder J, Gomes I, Rozenfeld R, Bushlin I, et al. Increased abundance of opioid receptor heteromers after chronic morphine administration. Sci Signal. 2010; 3:ra54. [PubMed: 20647592]

14. Berg KA, Rowan MP, Gupta A, Sanchez TA, Silva M, et al. Allosteric interactions between $\delta$ and $\kappa$ opioid receptors in peripheral sensory neurons. Mol Pharmacol. 2012; 81:264-72. [PubMed: 22072818]

15. Bushlin I, Gupta A, Stockton SD Jr, Miller LK, Devi LA. Dimerization with cannabinoid receptors allosterically modulates $\delta$ opioid receptor activity during neuropathic pain. PLOS ONE. 2012; 7:e49789. [PubMed: 23272051] 
16. Rozenfeld R, Gupta A, Gagnidze K, Lim MP, Gomes I, et al. AT1R-CB ${ }_{1}$ R heteromerization reveals a new mechanism for the pathogenic properties of angiotensin II. EMBO J. 2011; 30:235063. [PubMed: 21540834]

17. Hansen JL, Hansen JT, Speerschneider T, Lyngso C, Erikstrup N, et al. Lack of evidence for AT1R/B2R heterodimerization in COS-7, HEK293, and NIH3T3 cells: How common is the AT1R/B2R heterodimer? J Biol Chem. 2009; 284:1831-39. [PubMed: 19017652]

18. Frederick AL, Yano H, Trifilieff P, Vishwasrao HD, Biezonski D, et al. Evidence against dopamine D1/D2 receptor heteromers. Mol Psychiatry. 2015; 20:1373-85. [PubMed: 25560761]

19. Levsky JM, Singer RH. Fluorescence in situ hybridization: past, present and future. J Cell Sci. 2003; 116:2833-38. [PubMed: 12808017]

20. Chabot JG, Kar S, Quirion R. Autoradiographical and immunohistochemical analysis of receptor localization in the central nervous system. Histochem J. 1996; 28:729-45. [PubMed: 8968726]

21. Weibrecht I, Leuchowius KJ, Clausson CM, Conze T, Jarvius M, et al. Proximity ligation assays: a recent addition to the proteomics toolbox. Expert Rev Proteomics. 2010; 7:401-9. [PubMed: 20536310]

22. Jonas KC, Fanelli F, Huhtaniemi IT, Hanyaloglu AC. Single molecule analysis of functionally asymmetric G protein-coupled receptor (GPCR) oligomers reveals diverse spatial and structural assemblies. J Biol Chem. 2015; 290:3875-92. [PubMed: 25516594]

23. Jaeger WC, Armstrong SP, Hill SJ, Pfleger KDG. Biophysical detection of diversity and bias in GPCR function. Front Endocrinol. 2014; 5:26.

24. Hebert TE, Gales C, Rebois RV. Detecting and imaging protein-protein interactions during G protein-mediated signal transduction in vivo and in situ by using fluorescence-based techniques. Cell Biochem Biophys. 2006; 45:85-109. [PubMed: 16679566]

25. Ayoub M, Zhang Y, Kelly R, See H, Johnstone E, et al. Functional interaction between angiotensin II receptor type 1 and chemokine (C-C motif ) receptor 2 with implications for chronic kidney disease. PLOS ONE. 2015; 10:e0119803. [PubMed: 25807547]

26. Kocan M, Pfleger KDG. Study of GPCR-protein interactions by BRET. Methods Mol Biol. 2011; 746:357-71. [PubMed: 21607868]

27. Mercier JF, Salahpour A, Angers S, Breit A, Bouvier M. Quantitative assessment of $\beta 1$ - and $\beta 2$ adrenergic receptor homo- and heterodimerization by bioluminescence resonance energy transfer. J Biol Chem. 2002; 277:44925-31. [PubMed: 12244098]

28. Pfleger KDG, Eidne KA. Illuminating insights into protein-protein interactions using bioluminescence resonance energy transfer (BRET). Nat Methods. 2006; 3:165-74. [PubMed: 16489332]

29. Lohse MJ, Nuber S, Hoffmann C. Fluorescence/bioluminescence resonance energy transfer techniques to study G-protein-coupled receptor activation and signaling. Pharmacol Rev. 2012; 64:299-336. [PubMed: 22407612]

30. Albizu L, Cottet M, Kralikova M, Stoev S, Seyer R, et al. Time-resolved FRET between GPCR ligands reveals oligomers in native tissues. Nat Chem Biol. 2010; 6:587-94. [PubMed: 20622858]

31. Comps-Agrar L, Kniazeff J, Nørskov-Lauritsen L, Maurel D, Gassmann M, et al. The oligomeric state sets GABA $_{B}$ receptor signalling efficacy. EMBO J. 2011; 30:2336-49. [PubMed: 21552208]

32. Cottet M, Faklaris O, Falco A, Trinquet E, Pin JP, et al. Fluorescent ligands to investigate GPCR binding properties and oligomerization. Biochem Soc Trans. 2013; 41:148-53. [PubMed: 23356275]

33. Hounsou C, Margathe J, Oueslati N, Belhocine A, Dupuis E, et al. Time-resolved FRET binding assay to investigate hetero-oligomer binding properties: proof of concept with dopamine $\mathrm{D}_{1} / \mathrm{D}_{3}$ heterodimer. ACS Chem Biol. 2015; 10:466-74. [PubMed: 25350273]

34. Callén L, Moreno E, Barroso-Chinea P, Moreno-Delgado D, Cortés A, et al. Cannabinoid receptors $\mathrm{CB}_{1}$ and $\mathrm{CB}_{2}$ form functional heteromers in brain. J Biol Chem. 2012; 287:20851-65. [PubMed: 22532560]

35. Trifilieff P, Rives ML, Urizar E, Piskorowski RA, Vishwasrao HD, et al. Detection of antigen interactions ex vivo by proximity ligation assay: endogenous dopamine D2-adenosine A2A receptor complexes in the striatum. BioTechniques. 2011; 51:111-18. [PubMed: 21806555] 
36. Fuxe K, Borroto-Escuela D, Ciruela F, Guidolin D, Agnati L. Receptor-receptor interactions in heteroreceptor complexes: a new principle in biology. Focus on their role in learning and memory. Neurosci Discov. 2014; 2:6.

37. Koos B, Andersson L, Clausson CM, Grannas K, Klaesson A, et al. Analysis of protein interactions in situ by proximity ligation assays. Curr Top Microbiol Immunol. 2014; 377:111-26. [PubMed: 23921974]

38. Sierra S, Luquin N, Rico AJ, Gómez-Bautista V, Roda E, et al. Detection of cannabinoid receptors CB1 and CB2 within basal ganglia output neurons in macaques: changes following experimental parkinsonism. Brain Struct Funct. 2015; 220:2721-38. [PubMed: 24972960]

39. Berggard T, Linse S, James P. Methods for the detection and analysis of protein-protein interactions. Proteomics. 2007; 7:2833-42. [PubMed: 17640003]

40. Gomes I, Gupta A, Devi LA. G-protein-coupled heteromers: regulation in disease. Methods Enzymol. 2013; 521:219-38. [PubMed: 23351742]

41. Erbs E, Faget L, Scherrer G, Matifas A, Filliol D, et al. A $\mu-\delta$ opioid receptor brain atlas reveals neuronal co-occurrence in subcortical networks. Brain Struct Funct. 2014; 220:677-702. [PubMed: 24623156]

42. George SR, Fan T, Xie Z, Tse R, Tam V, et al. Oligomerization of $\mu$ - and $\delta$-opioid receptors. Generation of novel functional properties. J Biol Chem. 2000; 275:26128-35. [PubMed: 10842167]

43. Kabli N, Martin N, Fan T, Nguyen T, Hasbi A, et al. Agonists at the $\delta$-opioid receptor modify the binding of $\mu$-receptor agonists to the $\mu-\delta$ receptor hetero-oligomer. Br J Pharmacol. 2010; 161:1122-36. [PubMed: 20977461]

44. Baragli A, Alturaihi H, Watt HL, Abdallah A, Kumar U. Heterooligomerization of human dopamine receptor 2 and somatostatin receptor 2 co-immunoprecipitation and fluorescence resonance energy transfer analysis. Cell Signal. 2007; 19:2304-16. [PubMed: 17706924]

45. Rocheville M, Lange DC, Kumar U, Patel SC, Patel RC, Patel YC. Receptors for dopamine and somatostatin: formation of hetero-oligomers with enhanced functional activity. Science. 2000; 288:154-57. [PubMed: 10753124]

46. Wang D, Sun X, Bohn LM, Sadee W. Opioid receptor homo- and heterodimerization in living cells by quantitative bioluminescence resonance energy transfer. Mol Pharmacol. 2005; 67:2173-84. [PubMed: 15778451]

47. Pfeiffer M, Kirscht S, Stumm R, Koch T, Wu D, et al. Heterodimerization of substance $P$ and $\mu-$ opioid receptors regulates receptor trafficking and resensitization. J Biol Chem. 2003; 278:51630 37. [PubMed: 14532289]

48. Dasgupta S, Ferré S, Kull B, Hedlund PB, Finnman UB, et al. Adenosine $A_{2 A}$ receptors modulate the binding characteristics of dopamine $\mathrm{D}_{2}$ receptors in stably cotransfected fibroblast cells. Eur $\mathrm{J}$ Pharmacol. 1996; 316:325-31. [PubMed: 8982704]

49. Ferré S, von Euler G, Johansson B, Fredholm BB, Fuxe K. Stimulation of high-affinity adenosine $\mathrm{A}_{2}$ receptors decreases the affinity of dopamine $\mathrm{D}_{2}$ receptors in rat striatal membranes. PNAS. 1991; 88:7238-41. [PubMed: 1678519]

50. Albizu L, Holloway T, Gonzalez-Maeso J, Sealfon SC. Functional crosstalk and heteromerization of serotonin 5-HT $2 \mathrm{~A}$ and dopamine $\mathrm{D}_{2}$ receptors. Neuropharmacology. 2011; 61:770-77. [PubMed: 21645528]

51. Jordan BA, Devi LA. G-protein-coupled receptor heterodimerization modulates receptor function. Nature. 1999; 399:697-700. [PubMed: 10385123]

52. Gonzalez S, Moreno-Delgado D, Moreno E, Perez-Capote K, Franco R, et al. Circadian-related heteromerization of adrenergic and dopamine $\mathrm{D}_{4}$ receptors modulates melatonin synthesis and release in the pineal gland. PLOS Biol. 2012; 10:e1001347. [PubMed: 22723743]

53. Sohy D, Yano H, de Nadai P, Urizar E, Guillabert A, et al. Hetero-oligomerization of CCR2, CCR5, and CXCR4 and the protean effects of "selective" antagonists. J Biol Chem. 2009; 284:31270-79. [PubMed: 19758998]

54. Gomes I, Ijzerman AP, Ye K, Maillet EL, Devi LA. G protein-coupled receptor heteromerization: a role in allosteric modulation of ligand binding. Mol Pharmacol. 2011; 79:1044-52. [PubMed: 21415307] 
55. Gonzalez-Maeso J, Ang RL, Yuen T, Chan P, Weisstaub NV, et al. Identification of a serotonin/ glutamate receptor complex implicated in psychosis. Nature. 2008; 452:93-97. [PubMed: 18297054]

56. Rozenfeld R, Bushlin I, Gomes I, Tzavaras N, Gupta A, et al. Receptor heteromerization expands the repertoire of cannabinoid signaling in rodent neurons. PLOS ONE. 2012; 7:e29239. [PubMed: 22235275]

57. Zhu WZ, Chakir K, Zhang S, Yang D, Lavoie C, et al. Heterodimerization of $\beta 1$ - and $\beta 2$ adrenergic receptor subtypes optimizes $\beta$-adrenergic modulation of cardiac contractility. Circ Res. 2005; 97:244-51. [PubMed: 16002745]

58. McGraw DW, Mihlbachler KA, Schwarb MR, Rahman FF, Small KM, et al. Airway smooth muscle prostaglandin-EP1 receptors directly modulate $\beta 2$-adrenergic receptors within a unique heterodimeric complex. J Clin Investig. 2006; 116:1400-9. [PubMed: 16670773]

59. Fan T, Varghese G, Nguyen T, Tse R, O’Dowd BF, George SR. A role for the distal carboxyl tails in generating the novel pharmacology and $\mathrm{G}$ protein activation profile of $\mu$ and $\delta$ opioid receptor hetero-oligomers. J Biol Chem. 2005; 280:38478-88. [PubMed: 16159882]

60. Kabli N, Fan T, O'Dowd BF, George SR. $\mu-\delta$ Opioid receptor heteromer-specific signaling in the striatum and hippocampus. Biochem Biophys Res Commun. 2014; 450:906-11. [PubMed: 24976397]

61. Kern A, Albarran-Zeckler R, Walsh HE, Smith RG. Apo-ghrelin receptor forms heteromers with DRD2 in hypothalamic neurons and is essential for anorexigenic effects of DRD2 agonism. Neuron. 2012; 73:317-32. [PubMed: 22284186]

62. Charles AC, Mostovskaya N, Asas K, Evans CJ, Dankovich ML, Hales TG. Coexpression of $\delta$ opioid receptors with $\mu$ receptors in GH3 cells changes the functional response to mu agonists from inhibitory to excitatory. Mol Pharmacol. 2003; 63:89-95. [PubMed: 12488540]

63. Rozenfeld R, Devi LA. Receptor heterodimerization leads to a switch in signaling: $\beta$-arrestin2mediated ERK activation by $\mu-\delta$ opioid receptor heterodimers. FASEB J. 2007; 21:2455-65. [PubMed: 17384143]

64. Lin H, Trejo J. Transactivation of the PAR1-PAR2 heterodimer by thrombin elicits $\beta$-arrestinmediated endosomal signaling. J Biol Chem. 2013; 288:11203-15. [PubMed: 23476015]

65. Bellot M, Galandrin S, Boularan C, Matthies HJ, Despas F, et al. Dual agonist occupancy of $\mathrm{AT}_{1^{-}}$ $\mathrm{R}-\mathrm{a}_{2 \mathrm{C}}$-AR heterodimers results in atypical $\mathrm{G}_{\mathrm{s}}$-PKA signaling. Nat Chem Biol. 2015; 11:271-79. [PubMed: 25706338]

66. Wang HL, Hsu CY, Huang PC, Kuo YL, Li AH, et al. Heterodimerization of opioid receptor-like 1 and $\mu$-opioid receptors impairs the potency of $\mu$ receptor agonist. J Neurochem. 2005; 92:1285-94. [PubMed: 15748148]

67. Rios C, Gomes I, Devi LA. $\mu$ Opioid and CB1 cannabinoid receptor interactions: reciprocal inhibition of receptor signaling and neuritogenesis. Br J Pharmacol. 2006; 148:387-95. [PubMed: 16682964]

68. Pello OM, Martinez-Muñoz L, Parrillas V, Serrano A, Rodríguez-Frade JM, et al. Ligand stabilization of CXCR4/ $\delta$-opioid receptor heterodimers reveals a mechanism for immune response regulation. Eur J Immunol. 2008; 38:537-49. [PubMed: 18200497]

69. Carriba P, Ortiz O, Patkar K, Justinova Z, Stroik J, et al. Striatal adenosine $A_{2 A}$ and cannabinoid $\mathrm{CB}_{1}$ receptors form functional heteromeric complexes that mediate the motor effects of cannabinoids. Neuropsychopharmacology. 2007; 32:2249-59. [PubMed: 17356572]

70. Moreno JL, Holloway T, Gonzalez-Maeso J. G protein-coupled receptor heterocomplexes in neuropsychiatric disorders. Prog Mol Biol Trans Sci. 2013; 117:187-205.

71. Sohy D, Parmentier M, Springael JY. Allosteric transinhibition by specific antagonists in CCR2/ CXCR4 heterodimers. J Biol Chem. 2007; 282:30062-69. [PubMed: 17715128]

72. Chow BS, Kocan M, Bosnyak S, Sarwar M, Wigg B, et al. Relaxin requires the angiotensin II type 2 receptor to abrogate renal interstitial fibrosis. Kidney Int. 2014; 86:75-85. [PubMed: 24429402]

73. Leger AJ, Jacques SL, Badar J, Kaneider NC, Derian CK, et al. Blocking the protease-activated receptor 1-4 heterodimer in platelet-mediated thrombosis. Circulation. 2006; 113:1244-54. [PubMed: 16505172] 
74. Gomes I, Jordan BA, Gupta A, Trapaidze N, Nagy V, Devi LA. Heterodimerization of $\mu$ and $\delta$ opioid receptors: a role in opiate synergy. J Neurosci. 2000; 20:RC110. [PubMed: 11069979]

75. Gomes I, Gupta A, Filipovska J, Szeto HH, Pintar JE, Devi LA. A role for heterodimerization of $\mu$ and $\delta$ opiate receptors in enhancing morphine analgesia. PNAS. 2004; 101:5135-39. [PubMed: 15044695]

76. Hasbi A, Nguyen T, Fan T, Cheng R, Rashid A, et al. Trafficking of preassembled opioid $\mu-\delta$ heterooligomer-Gz signaling complexes to the plasma membrane: coregulation by agonists. Biochemistry. 2007; 46:12997-3009. [PubMed: 17941650]

77. Law PY, Erickson-Herbrandson LJ, Zha QQ, Solberg J, Chu J, et al. Heterodimerization of $\mu$ - and $\delta$-opioid receptors occurs at the cell surface only and requires receptor-G protein interactions. $\mathrm{J}$ Biol Chem. 2005; 280:11152-64. [PubMed: 15657030]

78. Pfeiffer M, Koch T, Schroder H, Laugsch M, Hollt V, Schulz S. Heterodimerization of somatostatin and opioid receptors cross-modulates phosphorylation, internalization, and desensitization. J Biol Chem. 2002; 277:19762-72. [PubMed: 11896051]

79. Hillion J, Canals M, Torvinen M, Casadó V, Scott R, et al. Coaggregation, cointernalization, and codesensitization of adenosine $\mathrm{A}_{2 \mathrm{~A}}$ receptors and dopamine $\mathrm{D}_{2}$ receptors. J Biol Chem. 2002; 277:18091-97. [PubMed: 11872740]

80. Torvinen M, Torri C, Tombesi A, Marcellino D, Watson S, et al. Trafficking of adenosine $\mathrm{A}_{2 \mathrm{~A}}$ and dopamine $\mathrm{D}_{2}$ receptors. J Mol Neurosci. 2005; 25:191-200. [PubMed: 15784967]

81. Milan-Lobo L, Whistler JL. Heteromerization of the $\mu$ - and $\delta$-opioid receptors produces ligandbiased antagonism and alters $\mu$-receptor trafficking. J Pharmacol Exp Ther. 2011; 337:868-75. [PubMed: 21422164]

82. Terrillon S, Barberis C, Bouvier M. Heterodimerization of V1a and V2 vasopressin receptors determines the interaction with $\beta$-arrestin and their trafficking patterns. PNAS. 2004; 101:154853. [PubMed: 14757828]

83. Mustafa S, See HB, Seeber RM, Armstrong SP, White CW, et al. Identification and profiling of novel $a_{1 A}$-adrenoceptor-CXC chemokine receptor 2 heteromer. J Biol Chem. 2012; 287:1295265. [PubMed: 22371491]

84. Decaillot FM, Kazmi MA, Lin Y, Ray-Saha S, Sakmar TP, Sachdev P. CXCR7/CXCR4 heterodimer constitutively recruits $\beta$-arrestin to enhance cell migration. J Biol Chem. 2011; 286:32188-97. [PubMed: 21730065]

85. Bulenger S, Marullo S, Bouvier M. Emerging role of homo- and heterodimerization in G-proteincoupled receptor biosynthesis and maturation. Trends Pharmacol Sci. 2005; 26:131-37. [PubMed: 15749158]

86. Hammad MM, Dupré DJ. Chaperones contribute to G protein-coupled receptor oligomerization, but do not participate in assembly of the $\mathrm{G}$ protein with the receptor signaling complex. J Mol Signal. 2010; 5:16. [PubMed: 20868491]

87. Abd Alla J, Reeck K, Langer A, Streichert T, Quitterer U. Calreticulin enhances B2 bradykinin receptor maturation and heterodimerization. Biochem Biophys Res Commun. 2009; 387:186-90. [PubMed: 19580784]

88. Decaillot FM, Rozenfeld R, Gupta A, Devi LA. Cell surface targeting of $\mu-\delta$ opioid receptor heterodimers by RTP4. PNAS. 2008; 105:16045-50. [PubMed: 18836069]

89. Ayoub MA, Pfleger KDG. Recent advances in bioluminescence resonance energy transfer technologies to study GPCR heteromerization. Curr Opin Pharmacol. 2010; 10:44-52. [PubMed: 19897419]

90. Mustafa S, Ayoub MA, Pfleger KDG. Uncovering GPCR heteromer-biased ligands. Drug Discov Today Technol. 2010; 7:e77-85.

91. Mustafa S, Pfleger KDG. G protein-coupled receptor heteromer identification technology: identification and profiling of GPCR heteromers. J Lab Autom. 2011; 16:285-91. [PubMed: 21764024]

92. Johnstone EK, Pfleger KDG. Receptor-heteromer investigation technology and its application using BRET. Front Endocrinol. 2012; 3:101. 
93. See HB, Seeber RM, Kocan M, Eidne KA, Pfleger KDG. Application of G protein-coupled receptor-heteromer identification technology to monitor $\beta$-arrestin recruitment to $G$ proteincoupled receptor heteromers. Assay Drug Dev Technol. 2011; 9:21-30. [PubMed: 21133678]

94. Porrello ER, Pfleger KDG, Seeber RM, Qian H, Oro C, et al. Heteromerization of angiotensin receptors changes trafficking and arrestin recruitment profiles. Cell Signal. 2011; 23:1767-76. [PubMed: 21740964]

95. Watts AO, van Lipzig MM, Jaeger WC, Seeber RM, van Zwam M, et al. Identification and profiling of CXCR3-CXCR4 chemokine receptor heteromer complexes. Br J Pharmacol. 2013; 168:1662-74. [PubMed: 23170857]

96. Schelshorn D, Joly F, Mutel S, Hampe C, Breton B, et al. Lateral allosterism in the glucagon receptor family: Glucagon-like peptide 1 induces G-protein-coupled receptor heteromer formation. Mol Pharmacol. 2012; 81:309-18. [PubMed: 22108912]

97. Armando S, Quoyer J, Lukashova V, Maiga A, Percherancier Y, et al. The chemokine CXC4 and $\mathrm{CC} 2$ receptors form homo- and heterooligomers that can engage their signaling G-protein effectors and $\beta$-arrestin. FASEB J. 2014; 28:4509-23. [PubMed: 25053617]

98. Gomes I, Fujita W, Gupta A, Saldanha SA, Negri A, et al. Identification of a $\mu-\delta$ opioid receptor heteromer-biased agonist with antinociceptive activity. PNAS. 2013; 110:12072-77. [PubMed: 23818586]

99. Stoddart LA, Johnstone EKM, Wheal AJ, Goulding J, Robers MB, et al. Application of BRET to monitor ligand binding to GPCRs. Nat Methods. 2015; 12:661-63. [PubMed: 26030448]

100. Daniels DJ, Lenard NR, Etienne CL, Law PY, Roerig SC, Portoghese PS. Opioid-induced tolerance and dependence in mice is modulated by the distance between pharmacophores in a bivalent ligand series. PNAS. 2005; 102:19208-13. [PubMed: 16365317]

101. Lenard NR, Daniels DJ, Portoghese PS, Roerig SC. Absence of conditioned place preference or reinstatement with bivalent ligands containing $\mu$-opioid receptor agonist and $\delta$-opioid receptor antagonist pharmacophores. Eur J Pharmacol. 2007; 566:75-82. [PubMed: 17383633]

102. Le Naour M, Akgün E, Yekkirala A, Lunzer MM, Powers MD, et al. Bivalent ligands that target $\mu$ opioid (MOP) and cannabinoid1 $\left(\mathrm{CB}_{1}\right)$ receptors are potent analgesics devoid of tolerance. J Med Chem. 2013; 56:5505-13. [PubMed: 23734559]

103. Yuan Y, Arnatt CK, El-Hage N, Dever SM, Jacob JC, et al. A bivalent ligand targeting the putative mu opioid receptor and chemokine receptor CCR5 heterodimers: binding affinity versus functional activities. Med Chem Commun. 2013; 4:847-51.

104. Akgün E, Javed MI, Lunzer MM, Smeester BA, Beitz AJ, Portoghese PS. Ligands that interact with putative MOR-mGluR5 heteromer in mice with inflammatory pain produce potent antinociception. PNAS. 2013; 110:11595-99. [PubMed: 23798416]

105. Bhushan RG, Sharma SK, Xie Z, Daniels DJ, Portoghese PS. A bivalent ligand (KDN-21) reveals spinal $\delta$ and $\kappa$ opioid receptors are organized as heterodimers that give rise to $\delta_{1}$ and $\kappa_{2}$ phenotypes. Selective targeting of $\delta$ - $\kappa$ heterodimers. J Med Chem. 2004; 47:2969-72. [PubMed: 15163177]

106. Yamamoto T, Nair P, Davis P, Ma SW, Navratilova E, et al. Design, synthesis, and biological evaluation of novel bifunctional C-terminal-modified peptides for $\delta / \mu$ opioid receptor agonists and neurokinin-1 receptor antagonists. J Med Chem. 2007; 50:2779-86. [PubMed: 17516639]

107. Journé A, Habib S, Dodda B, Morcos M, Sadek M, et al. N1-linked melatonin dimers as bivalent ligands targeting dimeric melatonin receptors. Med Chem Commun. 2014; 5:792-96.

108. Vardanyan R, Kumirov VK, Nichol GS, Davis P, Liktor-Busa E, et al. Synthesis and biological evaluation of new opioid agonist and neurokinin-1 antagonist bivalent ligands. Bioorg Med Chem. 2011; 19:6135-42. [PubMed: 21925887]

109. Largent-Milnes TM, Brookshire SW, Skinner DP Jr, Hanlon KE, Giuvelis D, et al. Building a better analgesic: multifunctional compounds that address injury-induced pathology to enhance analgesic efficacy while eliminating unwanted side effects. J Pharmacol Exp Ther. 2013; 347:719. [PubMed: 23860305]

110. Yekkirala AS, Lunzer MM, McCurdy CR, Powers MD, Kalyuzhny AE, et al. N-naphthoyl- $\beta$ naltrexamine (NNTA), a highly selective and potent activator of $\mu / \kappa$-opioid heteromers. PNAS. 2011; 108:5098-103. [PubMed: 21385944] 
111. Sevigny LM, Austin KM, Zhang P, Kasuda S, Koukos G, et al. Protease-activated receptor-2 modulates protease-activated receptor-1-driven neointimal hyperplasia. Arterioscler Thromb Vasc Biol. 2011; 31:e100-6. [PubMed: 21940952]

112. González S, Rangel-Barajas C, Peper M, Lorenzo R, Moreno E, et al. Dopamine $\mathrm{D}_{4}$ receptor, but not the ADHD-associated $\mathrm{D}_{4.7}$ variant, forms functional heteromers with the dopamine $\mathrm{D}_{2} \mathrm{~S}$ receptor in the brain. Mol Psychiatry. 2012; 17:650-62. [PubMed: 21844870]

113. Moreno JL, Muguruza C, Umali A, Mortillo S, Holloway T, et al. Identification of three residues essential for 5-hydroxytryptamine $2 \mathrm{~A}$-metabotropic glutamate $2\left(5-\mathrm{HT}_{2 \mathrm{~A}} \cdot \mathrm{mGlu} 2\right)$ receptor heteromerization and its psychoactive behavioral function. J Biol Chem. 2012; 287:44301-19. [PubMed: 23129762]

114. Baba K, Benleulmi-Chaachoua A, Journé AS, Kamal M, Guillaume JL, et al. Heteromeric $\mathrm{MT}_{1} / \mathrm{MT}_{2}$ melatonin receptors modulate photoreceptor function. Sci Signal. 2013; 6:ra89. [PubMed: 24106342]

115. Fujita W, Gomes I, Devi LA. Heteromers of $\mu-\delta$ opioid receptors: new pharmacology and novel therapeutic possibilities. Br J Pharmacol. 2015; 172:375-87. [PubMed: 24571499]

116. Fujita W, Gomes I, Devi LA. Revolution in GPCR signalling: opioid receptor heteromers as novel therapeutic targets: IUPHAR review 10. Br J Pharmacol. 2014; 171:4155-76. [PubMed: 24916280]

117. Gomes I, Gupta A, Bushlin I, Devi LA. Antibodies to probe endogenous G protein-coupled receptor heteromer expression, regulation, and function. Front Pharmacol. 2014; 5:268. [PubMed: 25520661]

118. Fink JS, Weaver DR, Rivkees SA, Peterfreund RA, Pollack AE, et al. Molecular cloning of the rat $\mathrm{A}_{2}$ adenosine receptor: selective co-expression with $\mathrm{D}_{2}$ dopamine receptors in rat striatum. Brain Res Mol Brain Res. 1992; 14:186-95. [PubMed: 1279342]

119. Bonaventura J, Rico AJ, Moreno E, Sierra S, Sánchez M, et al. L-DOPA-treatment in primates disrupts the expression of $\mathrm{A}_{2 \mathrm{~A}}$ adenosine- $-\mathrm{CB}_{1}$ cannabinoid $-\mathrm{D}_{2}$ dopamine receptor heteromers in the caudate nucleus. Neuropharmacology. 2014; 79:90-100. [PubMed: 24230991]

120. Fuxe K, Ferré S, Canals M, Torvinen M, Terasmaa A, et al. Adenosine $A_{2 A}$ and dopamine $D_{2}$ heteromeric receptor complexes and their function. J Mol Neurosci. 2005; 26:209-20. [PubMed: 16012194]

121. Cabello N, Gandía J, Bertarelli DCG, Watanabe M, Lluís C, et al. Metabotropic glutamate type 5, dopamine $\mathrm{D}_{2}$ and adenosine $\mathrm{A}_{2 \mathrm{a}}$ receptors form higher-order oligomers in living cells. $\mathrm{J}$ Neurochem. 2009; 109:1497-507. [PubMed: 19344374]

122. Soriano A, Ventura R, Molero A, Hoen R, Casadó V, et al. Adenosine A2A receptor- antagonist/ dopamine $\mathrm{D}_{2}$ receptor-agonist bivalent ligands as pharmacological tools to detect $\mathrm{A}_{2} \mathrm{~A}^{-} \mathrm{D}_{2}$ receptor heteromers. J Med Chem. 2009; 52:5590-602. [PubMed: 19711895]

123. Scholten DJ, Canals M, Maussang D, Roumen L, Smit MJ, et al. Pharmacological modulation of chemokine receptor function. Br J Pharmacol. 2012; 165:1617-43. [PubMed: 21699506]

124. Tripathi A, Vana PG, Chavan TS, Brueggemann LI, Byron KL, et al. Heteromerization of chemokine (C-X-C motif ) receptor 4 with $\mathrm{a}_{1 \mathrm{~A} / \mathrm{B}}$-adrenergic receptors controls a 1-adrenergic receptor function. PNAS. 2015; 112(13):E1659-68. [PubMed: 25775528]

125. Rashid AJ, So CH, Kong MM, Furtak T, El-Ghundi M, et al. D1-D2 dopamine receptor heterooligomers with unique pharmacology are coupled to rapid activation of $\mathrm{G}_{\mathrm{q}} / 11$ in the striatum. PNAS. 2007; 104:654-59. [PubMed: 17194762]

126. Ng J, Rashid AJ, So CH, O’Dowd BF, George SR. Activation of calcium/calmodulin-dependent protein kinase IIa in the striatum by the heteromeric D1-D2 dopamine receptor complex. Neuroscience. 2010; 165:535-41. [PubMed: 19837142]

127. Pei L, Li S, Wang M, Diwan M, Anisman H, et al. Uncoupling the dopamine D1-D2 receptor complex exerts antidepressant-like effects. Nat Med. 2010; 16:1393-95. [PubMed: 21113156]

128. Vilar M, Sung TC, Chen Z, Garcia-Carpio I, Fernandez EM, et al. Heterodimerization of p45-p75 modulates p75 signaling: structural basis and mechanism of action. PLOS Biol. 2014; 12:e1001918. [PubMed: 25093680]

129. Ludtke SJ, Serysheva II. Single-particle cryo-EM of calcium release channels: structural validation. Curr Opin Struct Biol. 2013; 23:755-62. [PubMed: 23831288] 
130. Bai XC, McMullan G, Scheres SHW. How cryo-EM is revolutionizing structural biology. Trends Biochem Sci. 2015; 40:49-57. [PubMed: 25544475]

131. Christopoulos A, Kenakin T. G protein-coupled receptor allosterism and complexing. Pharmacol Rev. 2002; 54:323-74. [PubMed: 12037145]

132. Haack KVV, McCarty NA. Functional consequences of GPCR heterodimerization: GPCRs as allosteric modulators. Pharmaceuticals. 2011; 4:509-23.

133. Urban JD, Clarke WP, von Zastrow M, Nichols DE, Kobilka B, et al. Functional selectivity and classical concepts of quantitative pharmacology. J Pharmacol Exp Ther. 2007; 320:1-13. [PubMed: 16803859]

134. Fujita W, Gomes I, Dove LS, Prohaska D, McIntyre G, Devi LA. Molecular characterization of

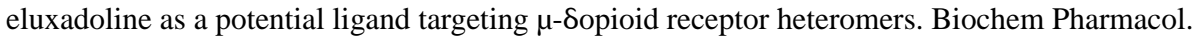
2014; 92:448-56. [PubMed: 25261794] 


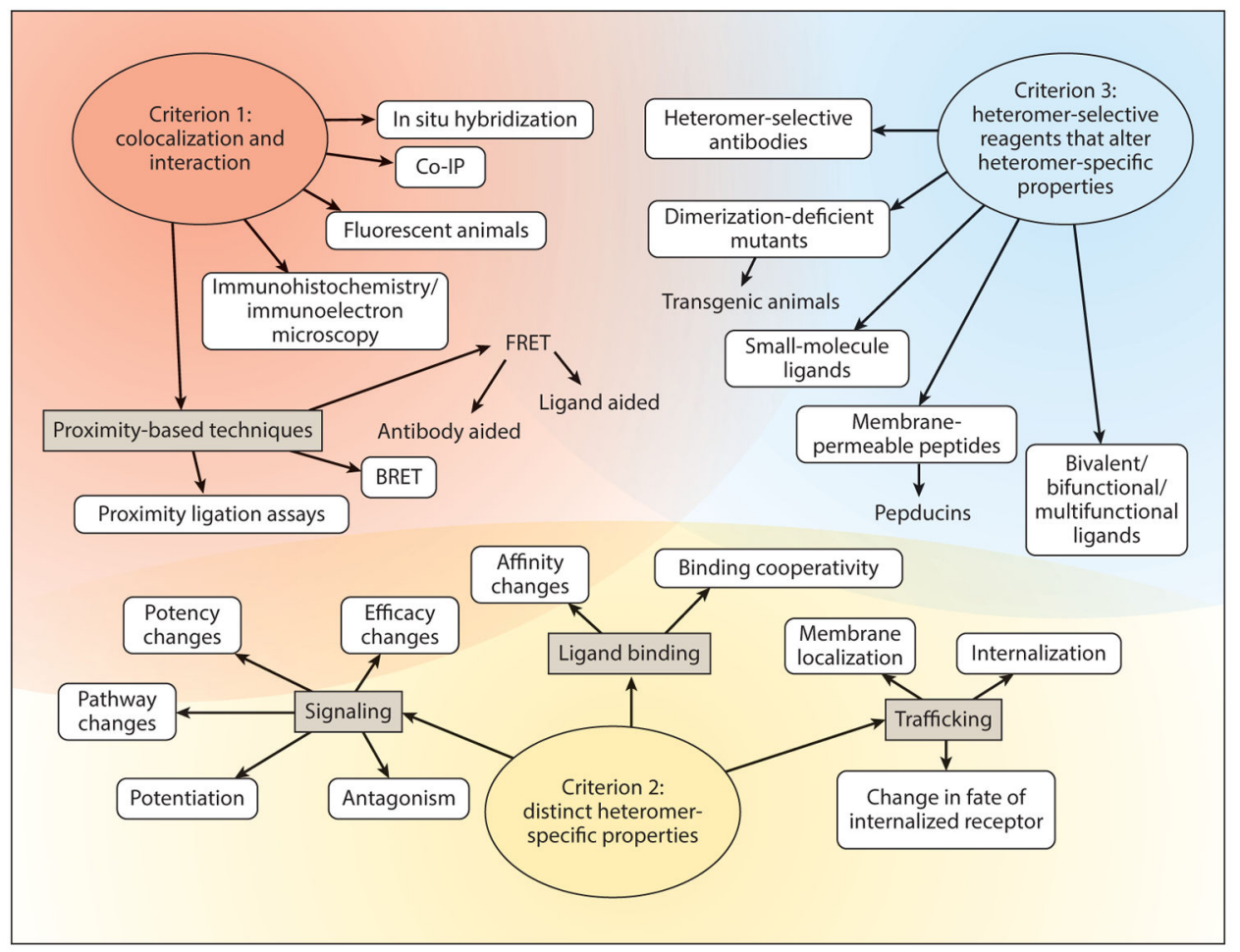

\section{Figure 1.}

The three criteria to establish $\mathrm{G}$ protein-coupled receptor heteromerization and approaches to address the criteria. Abbreviations: BRET, bioluminescence resonance energy transfer; Co-IP, coimmunoprecipitation; FRET, fluorescence resonance energy transfer. 
a

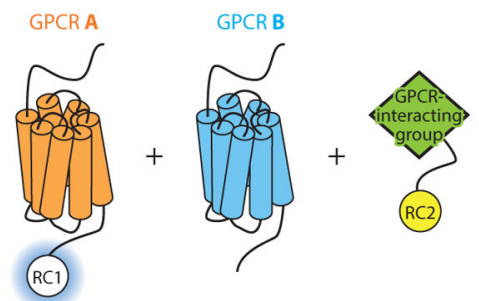

b

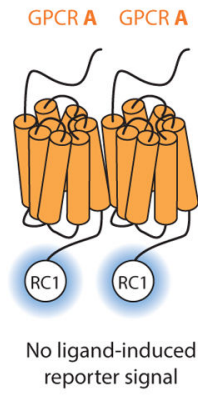

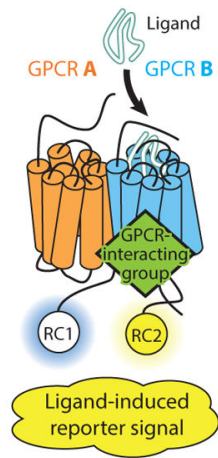

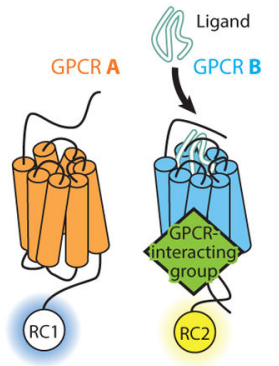

No ligand-induced reporter signal

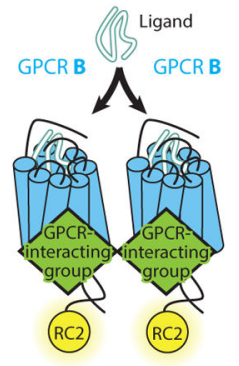

No ligand-induced reporter signal

Figure 2.

Characterizing novel heteromer-specific molecular pharmacology in heterologous systems.

(a) The G Protein-Coupled Receptor Heteromer Identification Technology (GPCR-HIT) is a configuration whereby GPCR A is tagged with one part of a proximity-based reporter system [reporter component 1 (RC1)], and GPCR B is untagged. A GPCR-interacting group (e.g., ligand, G protein, $\beta$-arrestin, another receptor or another region of GPCR A such as an intracellular loop) is then tagged with a complementary part of the same reporter system [reporter component 2 (RC2)]. (b) Activation of GPCR B or the A/B heteromer results in modulation of the proximity between $\mathrm{RC} 1$ and $\mathrm{RC} 2$. Monitoring the ligand-induced signal from the chosen reporter system [e.g., bioluminescence resonance energy transfer (BRET), fluorescence resonance energy transfer (FRET), enzyme fragment complementation] provides evidence for heteromer complex formation. 

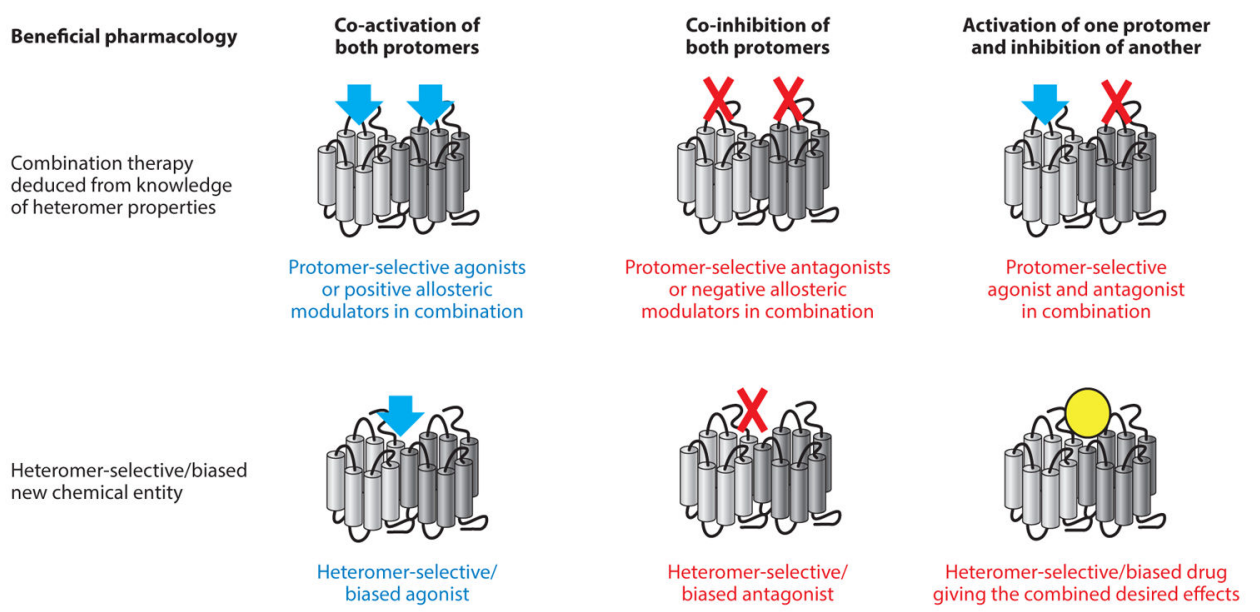

Figure 3.

Use of the knowledge of heteromerization to develop novel therapies. Once the physiological and/or pathological function of a heteromer compared with a monomer/ homomer is understood, one can elucidate how to modulate that function for therapeutic benefit. There are many options in this regard, examples of which are illustrated. It is important to note, however, that biased signaling may also need to be considered, and the desired pharmacology will potentially require a specific biased signaling profile that may also be cell context-dependent. The desired drug may need to act on monomers/homomers and select against modulating heteromers. Despite this knowledge, finding a suitable drug that fulfills these requirements still requires knowledge and screening of relevant heteromers in parallel with constituent protomers. 


\section{Table 1}

Examples of heteromers that fulfill the various criteria

\begin{tabular}{|c|c|c|c|}
\hline CNS heteromer & Criteria fulfilled & Non-CNS heteromer & Criteria fulfilled \\
\hline$\delta \mathrm{OR}-\mu \mathrm{OR}$ & $1,2,3$ & $\beta_{1} \mathrm{AR}-\beta_{2} \mathrm{AR}$ & 2,3 \\
\hline$\delta \mathrm{OR}-\mathrm{xOR}$ & 1,3 & $\beta_{2}$ AR-AT1 & 2 \\
\hline$\kappa \mathrm{OR}-\mu \mathrm{OR}$ & 3 & $\beta_{2}$ AR-EP1R & 2 \\
\hline$\mu$ OR-GRPR & 1,3 & $\beta_{2} \mathrm{AR}-\mathrm{B} 2 \mathrm{R}$ & 2,3 \\
\hline$\mu$ OR-NK1 & 3 & $a_{2 \mathrm{C}} \mathrm{AR}-\mathrm{AT} 1$ & 2 \\
\hline$\delta \mathrm{OR}-\mathrm{CB} 1$ & 2,3 & $a_{1 \mathrm{AB}} \mathrm{AR}-\mathrm{CXCR} 4$ & $1,2,3$ \\
\hline$\mu$ OR-CB1 & 3 & AT1-ETB & 1,2 \\
\hline A2A-CB1 & 1,2 & AT1-PGF2R & 2 \\
\hline D2R-OTR & 1,2 & ETA-ETB & 1,2 \\
\hline D2R-GSHR1a & 1,2 & AT1-CB1 & 1,3 \\
\hline $\mathrm{A} 1-\mathrm{A} 2 \mathrm{~A}$ & 1,2 & AT2-RXFP1 & 2,3 \\
\hline A1-mGlu $1 a$ & 1,2 & PAR1-PAR2 & 2,3 \\
\hline A2A-D2R & $1,2,3$ & PAR3-PAR4 & 2 \\
\hline $\mathrm{A} 2 \mathrm{~A}-\mathrm{mGlu}_{5}$ & 1,2 & PAR1-PAR4 & 2 \\
\hline D1R-D2R ${ }^{a}$ & $1,2,3$ & PAR1-PAR3 & 2 \\
\hline $5-\mathrm{HT}_{2 \mathrm{~A}}-\mathrm{D} 2 \mathrm{R}$ & 2 & PAR2-PAR3 & 2 \\
\hline CRHR1-V1bR & 2 & CXCR4-CXCR7 & 2 \\
\hline $5-\mathrm{HT}_{2 \mathrm{~A}}-\mathrm{mGlu}_{2}$ & 1,3 & ChemR23-CCR7 & 2 \\
\hline D2SR-D4R & 2,3 & ChemR23-CXCR4 & 2 \\
\hline $\mathrm{MT}_{1}$-GPR50 & 2 & AT1-CCR2 & 2 \\
\hline $5-\mathrm{HT}_{2 \mathrm{C}}-\mathrm{MT}_{2}$ & 3 & $\mu \mathrm{OR}-\mathrm{CCR} 5$ & 2 \\
\hline$a_{1 B}$ AR-D4R & 1,2 & CCR2-CCR5 & 2,3 \\
\hline$\beta{ }_{1}$ AR-D4R & 1,2 & CCR2-CXCR4 & 2,3 \\
\hline D2R-SSTR2 & 3 & CCR5-CXCR4 & 2,3 \\
\hline \multirow[t]{2}{*}{ AT1-SCTR } & 3 & GPR55/CB2 & 1,2 \\
\hline & & $\mathrm{MT}_{1}-\mathrm{MT}_{2}$ & $1,2,3$ \\
\hline
\end{tabular}

The criteria are as follows: Criterion 1: Heteromers should exhibit appropriate colocalization and interaction to enable allosterism. Criterion 2: Heteromers should exhibit distinct properties. Criterion 3: Heteromer-selective reagents should alter heteromer properties. Highlighted in red are heteromers that fulfill all three criteria. Note that criterion 1 is considered fulfilled if there is evidence from proximity-based assays and/or both colocalization and coimmunoprecipitation. Green text indicates heteromers that appear to fulfill all three criteria but for which the evidence is contradictory. For additional details, readers are referred to Supplemental Tables 1 and 2. Abbreviation: CNS, central nervous system.

Evidence for heteromerization in native tissue is contradicted in Reference 18. 